ENTREPRENEURSHIP AND SUSTAINABILITY ISSUES

ISSN 2345-0282 (online) http://jssidoi.org/jesi/ 2021 Volume 9 Number 2 (December) http://doi.org/10.9770/jesi.2021.9.2(3)



http://jssidoi.org/esc/home

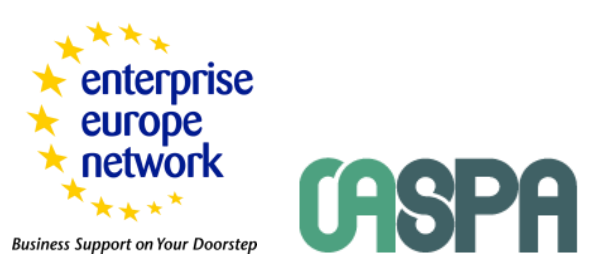

Business Support on Your Doorstep

1 Clarivate

Analytics

\title{
DETERMINANTS OF THE HUMAN CAPITAL REDISTRIBUTION. WHAT PUSHES OUT AND WHAT PULLS TO THE REGIONS OF MASOVIAN VOIVODSHIP*
}

\author{
Marek Piotrowski ${ }^{1}$, Paweł Huras ${ }^{2}$, Katarzyna Modrzejewska ${ }^{3}$ \\ ${ }^{1}$ Department of Economic Policy, Institute of Economics and Finance, Faculty of Economic Sciences, University of Warmia \\ and Mazury in Olsztyn, Oczapowskiego 4, 10-719 Olsztyn, Poland \\ ${ }^{2}$ Research and Analysis Department, Centre for Innovation and Technology Transfer Management, Faculty of Management, \\ Warsaw University of Technology, Ludwika Narbutta 85, 02-524 Warsaw, Poland \\ ${ }^{3}$ Research and Analysis Department, Centre for Innovation and Technology Transfer Management, Warsaw University of \\ Technology, Rektorska 4, 00-614 Warsaw, Poland
}

E-mails:1ํㅡㄹiotrowski@uwm.edu.pl; ${ }^{2}$ pawel.huras.dokt@pw.edu.pl; ${ }^{3}$ katarzyna.modrzejewska@pw.edu.pl

Received 18 July 2021; accepted 10 October 2021; published 30 December 2021

\begin{abstract}
Increase in human capital is one of the paths to sustainable development. The issue of determinants of redistribution, concentration and dispersion of human capital has been a research topic undertaken by representatives of broadly understood social sciences. It is worth mentioning that one of the basic factors determining the concentration of the discussed resources, as well as their dispersion, are the processes of population migration, which are a derivative of, inter alia, the differentiation of the attractiveness of particular areas. This paper deals with the issue of the level of human capital as one of the key determinants of the socio-economic development of Mazovia. The main aim of this paper is to diagnose the factors pushing out of and attracting human resources to the regions of the Masovian Voivodship. The survey on a representative sample of $n=1,233$ employers whose business activity is registered in the Warsaw capital region and Mazowieckie region (NUTS 2) was carried out using two research techniques: CATI and CAWI. Statistical inference was carried out using non-parametric tests. The relationships between the variables were tested with the $\chi^{2}$ test. The MannWhitney $U$ test was used to study the relationship between two independent groups. This paper indicates the key factors pushing human resources out of individual regions and the factors that, according to employers, encourage people to settle in the Warsaw capital region and Mazowieckie region. Particular attention was paid to factors related to the availability of educational institutions, health care facilities, cultural institutions, the level of wages, costs of living, investment attractiveness and the so-called environmental values.
\end{abstract}

Keywords: human capital, migration; push and pull factors; Masovian Voivodship; regions

Reference to this paper should be made as follows: Piotrowski, M., Huras, P., Modrzejewska, K. 2021. Determinants of the human capital redistribution. What pushes out and what pulls to the regions of Masovian voivodship. Entrepreneurship and Sustainability Issues, 9(2), 50-64. http://doi.org/10.9770/jesi.2021.9.2(3)

\footnotetext{
* The study was carried out as part of the "Sustainable development of the Masovian Voivodship in the new system of NUTS2 and NUTS3 units. Metropolitan, regional and sub-regional level "project, implemented under the strategic research and development program: "Social and economic development of Poland in the conditions of globalizing markets GOSPOSTRATEG". The project was financed by the National Centre for Research and Development (grant agreement number: Gospostrateg1/388207/9/NCBR/2018).
} 


\section{ENTREPRENEURSHIP AND SUSTAINABILITY ISSUES}

ISSN 2345-0282 (online) http://jssidoi.org/jesi/ 2021 Volume 9 Number 2 (December) http://doi.org/10.9770/jesi.2021.9.2(3)

JEL Classifications: E24, R23, O15

\section{Introduction}

In economic sciences, changes taking place in the economy are perceived from the aspect of economic growth and socio-economic development. One of the most important determinants of those changes is human capital available in the economy of a country or a single individual region (Kijek, Matras-Bolibok, 2020).

Determinants of redistribution, concentration and dispersion of human capital still remain a popular research topic undertaken by representatives of broadly understood social sciences. It is worth noting here that the process of population migration is one of the basic factors determining the concentration and dispersion of human capital. Migration itself results from many factors with the diversification of the attractiveness of individual economic regions being the most important one.

It should be emphasized that there are numerous barriers to objective measurement of human capital levels. There are commonly accepted indicators used to measure it, but significant differences exist between those indicators, especially when various levels of analysis are considered to compare countries or regions and to analyse human capital within them. Therefore, one of the important research challenges is the diagnosis of the determinants of the level of human capital in particular areas.

This study concerns the human capital level as one of the keydeterminants of the socio-economic development of Mazovia and we emphasized its significant dispersion. Therefore the aim of our research was to diagnose the factors pushing out and attracting human resources to individual regions of the Masovian Voivodship. A survey method on a representative sample of $n=1233$ employers whose business activity at the time of conducting research was registered in the Warsaw capital region and Mazowieckie region (NUTS 2) was adopted and performed using two research techniques: CATI (Computer Assisted Telephone Interview) and CAWI (Computer Assisted Web Interview). The obtained data made it possible to diagnose the key determinants of the differentiation of the level of human capital in individual regions of the Masovian Voivodship and to answer the research question posed in the title of this article: what pushes and what attracts people to particular areas of the voivodship under study?

The second part of this paper presents the results of the literature review in the field of determinants of the level of human capital and its importance in the context of growth and economic development of regions.. Moreover, various theories of population migration are briefly discussed. Research methodology is then explained in the third section, including sampling process, the course of the study and the scope of activities aimed at ensuring high quality and reliability of the obtained data. This is followed by interpretation of results. The whole study ends with a summary and a comparison with results obtained in other research initiatives.

\section{Theoretical background}

Adam Smith was the first to mention human capital and analysed it in the context of acquiring talents during the education process, which leads to the subsequent enrichment of society. However, T.W Schulz (1961) and G.S Becker (1962) were the first to use this concept in the literature. The considerations of T.W Schulz indicated the importance of the concept of human capital in the context of explaining certain economic anomalies. He actually emphasized the importance of human capital and considered it as another factor, next to labour, land and capital that influences economic growth (Goldin, 2019). T.W. Schulz saw investment in human capital primarily as expenditure on education and health care, paying attention to the importance of broadly understood migration processes (Schultz, 1961). G.S. Becker had a similar view. He claimed that investments in education and health 


\section{ENTREPRENEURSHIP AND SUSTAINABILITY ISSUES}

ISSN 2345-0282 (online) http://jssidoi.org/jesi/ 2021 Volume 9 Number 2 (December) http://doi.org/10.9770/jesi.2021.9.2(3)

protection, as well as gaining experience during work are in fact investments in human capital (Dańska-Borysiak, Laskowska, 2016, pp. 31-44). In his research, he pointed out, among other things, the influence of education and professional experience on the level of earnings (see Becker, 1962).

The roles of human capital in the context of regional development have been well described in the works of R. Lucas. He created two versions of the human capital model, differing in the ways in which an individual accumulates this capital (see Herbst, 2007, pp. 28). In addition, N.G. Mankiwa, D. Romer and D. Weil (1992) made their contribution by taking into account the process of accumulation of human capital using Solov model. On the other hand, D. Romer argued that human capital resources are the key factors influencing the development of the economy. In the endogenous growth model, he indicated that the initial level of human capital enables the prediction of the investment rate and indirectly influences the future rate of income growth (Romer, 1989; Zajączkowska-Jakimiak, 2006, pp. 47-69). Moreover, D. Romer's model assumed the existence of four production factors: physical capital, labor, human capital and technology (see Przygodzki, 2019, pp. 105-130). The views of both R. Lucas and D. Romer was continued by C.I. Jones. In his concept, human capital is a condition for the development of technology, while the technologies themselves contribute to economic growth and further increase in the level of human capital (see Niedzielski et al., 2009, p. 318).

In deliberations on the theory of human capital, it should also be mentioned R. Florida, who in the model of the creative class indicated that the concentration of human capital is more important than the concentration and number of enterprises in a given area (see Florida, 2002, p. 221). It is also worth mentioning the unified theory of economic growth by $\mathrm{O}$. Galor. It shows the key role of human capital in contemporary development processes. In this theoretical approach, the accumulated human capital is perceived as the engine of economic development (Przygodzki, 2019, pp. 105-130).

Despite some differences in the way the human capital is perceived and understood, it has been agreed that it has certain undeniable features (Kuc-Czarnecka, 2019). It is intangible and may change in the process of education and gaining professional experience (Bartnik, 2016, p. 7-26). The theoretical concepts presented in this study also allow to indicate a clear relationship between the level of human capital and the level of economic development achieved. As noted by Z. Przygodzki (2019, p. 105-130) on the basis of the theory of growth, there is agreement among individual authors that in order to achieve long-term economic growth, traditional factors of production are not sufficient.

Among the numerous research initiatives focused on the issue of human capital, a number of works presenting the results of research on its relationship with socio-economic development as well as regional and local development can be indicated. Some of them are listed below (Table 1). 


\section{ENTREPRENEURSHIP AND SUSTAINABILITY ISSUES}

ISSN 2345-0282 (online) http://jssidoi.org/jesi/ 2021 Volume 9 Number 2 (December) http://doi.org/10.9770/jesi.2021.9.2(3)

Table 1. Review of literature

\begin{tabular}{|l|l|}
\hline Publication & Main conclusions from the conducted research \\
\hline (Outreville, 1999) & $\begin{array}{l}\text { There is a strong positive correlation between financial development measures and the level of human } \\
\text { capital. }\end{array}$ \\
\hline $\begin{array}{l}\text { (Lee, et al., 2002, pp. } \\
879-891)\end{array}$ & $\begin{array}{l}\text { In the context of migration, regions characterized by high openness and social differentiation are more } \\
\text { likely to attract human capital. }\end{array}$ \\
\hline $\begin{array}{l}\text { (Williams, et al., 2004, } \\
\text { pp. 27-46) }\end{array}$ & $\begin{array}{l}\text { The carriers of human capital are individuals who migrate. In addition, researchers point to the need to } \\
\text { include the issues of migration and human capital mobility into the debate about the knowledge-based } \\
\text { economy and self-learning regions. }\end{array}$ \\
\hline $\begin{array}{l}\text { (Faggian \& McCann, } \\
\text { 2009) }\end{array}$ & $\begin{array}{l}\text { The migration of human capital influences the diversification of the nature of its development. The biggest } \\
\text { beneficiaries of migration are metropolises that attract human capital. }\end{array}$ \\
\hline $\begin{array}{l}\text { (Gennaioli, et al., 2013, } \\
\text { pp. 105-164) }\end{array}$ & $\begin{array}{l}\text { Collected evidence from 1.500 regions of each country shows a relationship between the level of } \\
\text { education and the achieved level of development of a region. Highly educated employees and } \\
\text { entrepreneurs increase productivity. }\end{array}$ \\
\hline $\begin{array}{l}\text { (Tselios, et al., 2017) } \\
\text { Two factors strongly influencing the economic development of Greece are human capital (i.e. education) } \\
\text { and transport infrastructure (i.e. road and rail). }\end{array}$ \\
\hline $\begin{array}{l}\text { (Diebolt \& Hippe, 2018, } \\
\text { pp. 542-563) }\end{array}$ & $\begin{array}{l}\text { From the perspective of historical data from 1850-1960, human capital was the most important factor } \\
\text { influencing the number of patent applications per capita. Human capital is an indicator of the current } \\
\text { disproportions in the development of individual regions in Europe. }\end{array}$ \\
\hline
\end{tabular}

When considering the level of human capital and its impact on the socio-economic development of regions, the process of population migration needs to be taken into account. The phenomenon of migration determines the size of the labour resources available in a given economy, and thus affects the structure of society from the point of view of such features as the level of education or age. The migratory movement of the population must therefore be understood as the displacement of human resources, and thus also of the human capital accumulated by each individual.

The relationship between different migration theories should also be emphasized with the issue of economic growth and development of regions experiencing the phenomenon of population migration. Theory of migration derived from Neoclassical Economics are useful in explaining the mechanism of economic migration and its various consequences for both areas, between which migration takes place (see Harris \& Todaro, 1970; Massey, et. 2006). There is also a dual labour market theory, which indicates the most important reasons for the occurrence of demand for external labour resources, understood as a natural phenomenon that occurs at a certain stage of socio-economic development (see Doeringer, Piore, 1971; Piore, 1979).

Selected migration theories may find their application in research on the determinants of the level of human capital and thus also in the socio-economic development of regions. An example of such an approach is "PushPull Factors Theory" by E.S. Lee. According to this theory, there are factors that encourage or discourage making migration decisions and can be noted both on the side of the place of origin and the destination of a possible migration. Importantly and unfortunately quite often overlooked in analyses of migration theory, there are also factors that are neutral in nature (Lee, 1966). In this context, it seems that research tools used to diagnose features that push out from a given area and features that attract people to a given area, and thus influencing the level of its development may to a large extent be based on the assumptions of the discussed theoretical approach.

\section{Research objective and methodology}

The primary aim of the study was to identify push factors and those that attract human resources to individual regions of the Masovian Voivodship (analysis at the level of NUTS 2 units). In the first stage of designing the research methodology, a selection was made of the main factors that may attract human resources or contribute to 


\section{ENTREPRENEURSHIP AND SUSTAINABILITY ISSUES}

ISSN 2345-0282 (online) http://jssidoi.org/jesi/ 2021 Volume 9 Number 2 (December) http://doi.org/10.9770/jesi.2021.9.2(3)

stimulating the phenomenon of emigration from a given area, thus constituting determinants of the level of socioeconomic development. The list of selected determinants is presented below (Table 2).

Table 2. Selected determinants of the level of socio-economic development

\begin{tabular}{|c|c|}
\hline Push factor / pull factor & References \\
\hline Availability of educational institutions (EDU) & $\begin{array}{l}\text { (Pritchett, 2001, pp. 367-391); (Horii, et al., 2008, pp. 156-177); (Aghion, } \\
\text { et al., 2009, pp. 1-73); (Donou-Adonsou, 2019, pp. 353-360). }\end{array}$ \\
\hline Availability and level of healthcare (HEALTH) & $\begin{array}{l}\text { (Alhowaish, 2014, pp. 1471-1476); (Bedir, 2016, pp. 76-86); (Som, 2019, } \\
\text { pp. 45-57). }\end{array}$ \\
\hline Number of jobs (JOB) & $\begin{array}{l}\text { (Seyfried, 2005, pp. 13-24); (Akcoraoglu, 2010, pp. 101-114); } \\
\text { (Simionescu, } \text { et al., 2017, pp. 103-116). }\end{array}$ \\
\hline The level of earnings (WAGE) & $\begin{array}{l}\text { (Pasinetti, 1962, pp. 267-279); (Bilan, et al., 2017, pp. 208-214); (Amri, } \\
\text { 2018, pp. 163-176). }\end{array}$ \\
\hline Costs of living (COST) & $\begin{array}{l}\text { (Bove \& Elia, 2017, pp. 227-239); (Humphries \& Weistorf, 2019, pp. 1- } \\
\text { 21). }\end{array}$ \\
\hline Environmental / recreational values (ENVIR) & $\begin{array}{l}\text { (Grossman \& Krueger, 1995, pp. 353-377); (Panayotou, 2016, pp. 140- } \\
\text { 148); (Khoshnevis \& Khanalizadeh, 2017, pp. 1181-1190). }\end{array}$ \\
\hline $\begin{array}{l}\text { Level of communication with important centers } \\
\text { (COMMUN) }\end{array}$ & $\begin{array}{l}\text { (Herranz-Loncán, 2007, pp. 452-468); (Banerjee, et al., 2012); (Toader, et } \\
\text { al., 2018). }\end{array}$ \\
\hline Accessibility of utility infrastructure (UTIL) & $\begin{array}{l}\text { (Cutanda \& Paricio, 1994, pp. 69-74); (Jerome, 2011, pp. 127-151); } \\
\text { (Palei, 2015, pp. 168-175); (Tian \& Li, 2019, pp. 3332-3348). }\end{array}$ \\
\hline Accessibility of cultural institutions (CULTUR) & $\begin{array}{l}\text { (Bakhshi, et al., 2015); (Angelini \& Castellani, 2019, pp. 173-188); } \\
\text { (Wiśniewska, et al., 2020, pp. 563-587). }\end{array}$ \\
\hline
\end{tabular}

Our survey was conducted on a representative sample of business owners registered in the Warsaw capital region and Mazowieckie region (NUTS 2). We used two research techniques: CATI (Computer Assisted Telephone Interview) and CAWI (Computer Assisted Web Interview). It should be kept in mind that not only employers have a wide range of knowledge about the factors that attract and push human resources out of a given area. In this study, however, a decision was made about assigning them to a role of respondents. It was dictated by the fact that employers conducting business activity in a given region often have expert knowledge on the widely understood level of attractiveness of a given area, which may ensure a relatively high value of the results obtained.

Samples were stratified and randomized. The region was the layer in the NUTS 2 statistical division. The following parameters were adopted: confidence level $=0.95$, proportion of the phenomenon in the general population $\mathrm{P}=50 \%$, maximum estimation error $\mathrm{e}=4 \%$. In order to determine the minimum size of a representative sample in individual strata, the formula was used: 
$\mathrm{n}=$ sample size;

$$
n=\frac{N\left(Z^{2} * P(1-P)\right)}{N * e^{2}+Z^{2} * P(1-P)}
$$

$\mathrm{N}=$ population size;

$\mathrm{e}=$ the maximum allowable error of estimation;

$\mathrm{P}=$ estimated proportion in the population;

$\mathrm{Z}=$ value of $\mathrm{Z}$ resulting from the adopted confidence level (0.95).

Using the Local Data Bank of the Central Statistical Office, the number of entities of the national economy registered in individual regions within Masovian Voivodship was determined:

Warsaw capital region $\mathrm{N} 1=495.190$;

Mazowieckie region N2 $=154.908$ (as of August 18, 2020).

The minimum size of a representative research sample was calculated in the regions:

NUTS 2 Warsaw capital region:

$$
600=\frac{495190\left(1,96^{2} * 0,5(1-0,5)\right)}{495190 * 0,04^{2}+1,96^{2} * 0,5(1-0,5)}
$$

NUTS 2 Mazowieckie region:

$$
598=\frac{154908\left(1,96^{2} * 0,5(1-0,5)\right)}{154908 * 0,04^{2}+1,96^{2} * 0,5(1-0,5)}
$$

In total, 631 respondents took part in the survey from the Warsaw capital region, and 602 respondents from Mazowieckie region. The survey was carried out between September 21 and October 23, 2020. Out of all 1233 interviews, 860 interviews were conducted using the CATI technique, and 373 interviews were conducted using the CAWI technique. During the study, the work of the interviewers was controlled. The field control method was used, consisting in the ongoing wiretapping during the interviews and non-field control, consisting in a comprehensive analysis of the database aggregating the results of the study.

During the audit, the following were verified:

- the fact of the interview taking place;

- the fact of conducting an interview with the appropriate employer;

- the fact of asking all the questions contained in the questionnaire;

- correctness of the use of filtering questions;

- correctness of asking questions (as stated in the questionnaire, without changing the wording, translating questions, forcing answers);

- substantive correctness of asking questions.

95 phone call conversations were analysed, which accounted for over $11 \%$ CATI interviews and all CAWI interviews. The interviews were conducted by 12 interviewers, all of them were controlled by telephone wiretapping. The interviewers who found irregularities during the wiretapping were informed about it on an ongoing basis and instructed on the appropriate manner of conducting the interviews. The mistakes made by them were corrected.

Non-field control of the study was conducted in order to verify the correctness of the respondents' answers. The 
subject of the audit was the database of the results of the study, which was verified in terms of:

- correctly entered respondents' answers to semi-open questions (without using abbreviations, incomplete entries);

- correct marking of respondents' answers in closed questions;

- substantive/logical answers.

Thanks to the use of two methods of quality control of the research implementation, potential errors and shortcomings were significantly reduced, which contributed to the quality of the results obtained in the empirical study.

\section{Results and discussion}

In our survey we asked respondents to analyse the proposed set of factors in the context of their role in attracting or pushing human resources out of a given region. In accordance with the assumptions of the previously quoted "Push and Pull Factors Theory" by E. Lee, the respondents were also given the option to describe the factor as "neutral", which is understood as having no effect.

It is worth noting that the collective analysis of the responses, without taking into account the division according to NUTS 2 units, authorizes the statement that the surveyed employers more often pointed to the attracting role of the factors proposed in the cafeteria, which may indicate that they see many advantages of the area in which they conduct their business. The only factor with a similar number of positive and negative responses (with a difference of 5 percentage points) was the cost of living. The most indications for the neutrality of the factor were those related to availability and level of healthcare (46.6\%), availability of educational institutions (46.6\%) and cultural institutions (40.9\%). List of respondents' responses according to their geographical location (either Warsaw capital region or Mazowieckie region) is presented in Figure 1. 
ENTREPRENEURSHIP AND SUSTAINABILITY ISSUES

ISSN 2345-0282 (online) http://jssidoi.org/jesi/ 2021 Volume 9 Number 2 (December) http://doi.org/10.9770/jesi.2021.9.2(3)

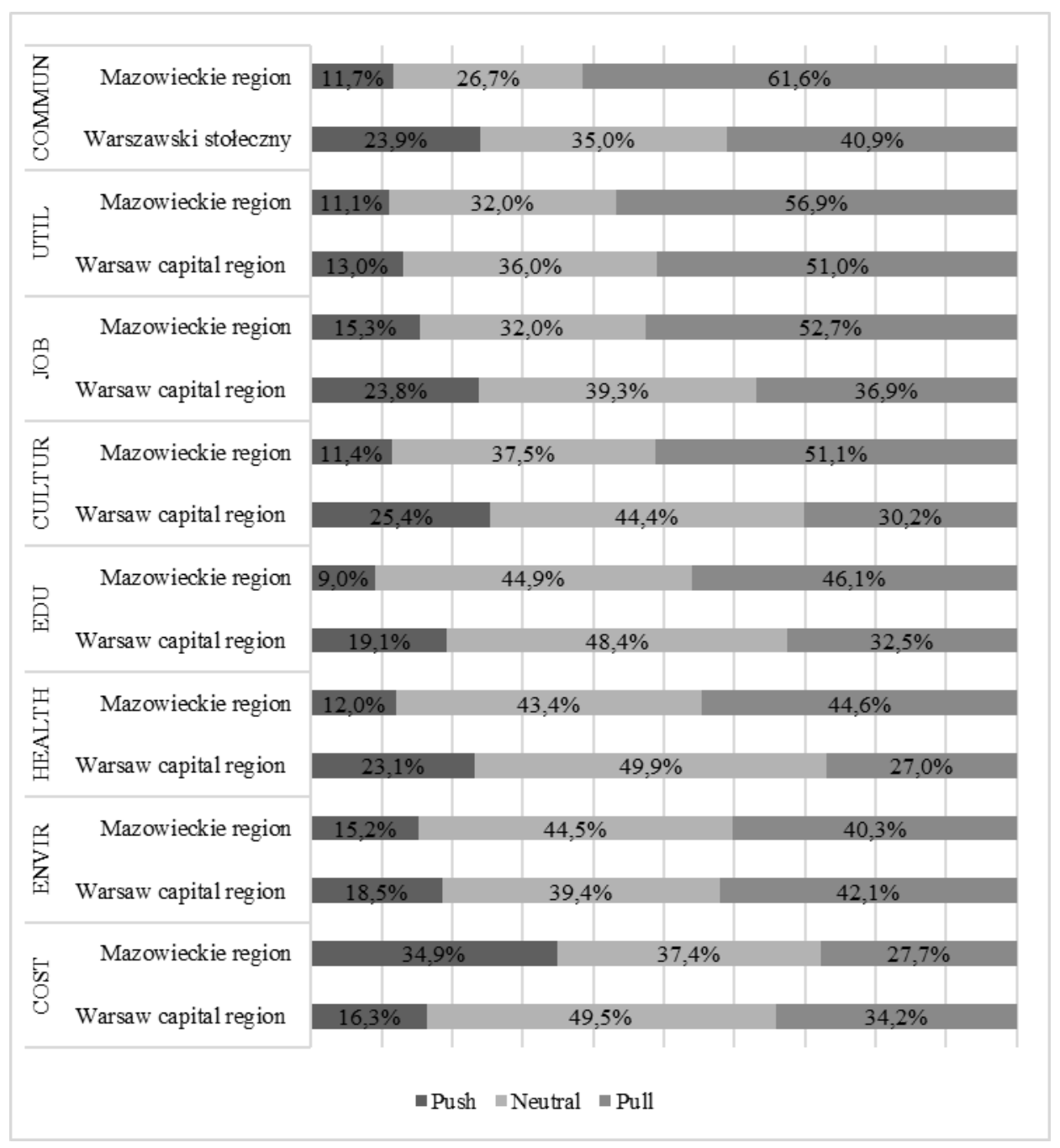

Figure 1. Factors pushing out of and attracting human capital to the regions of the Masovian Voivodship Source: own study based on the results of the CATI and CAWI survey on a sample of $\mathrm{n}=1,233$ employers.

Among the most often referred to as attractants, respondents from NUTS 2 Warsaw capital region indicated the level of communication with important centres (COMMUN), the accessibility of utility infrastructure (UTIL), the number of jobs (JOB) and the accessibility of cultural institutions (CULTUR). Each of the above-mentioned factors was indicated as attractive by over half of the respondents from the discussed region. In the opinion of employers from NUTS 2 Mazowieckie region, the attracting factors were dominated by the availability and level of health care (HEALTH) and the costs of living (COST).

In order to observe differences between the regions under study, em-ployers were divided into two categories. This division was separate and exhaustive, meaning that each participant could be assigned to only one category. Statistical inference was performed using non-parametric tests due to the ordinal level of measurement of variables and their qualitative nature at most. The relationships between the variables were tested with the independence test $\chi^{2}$. U Mann-Whitney tests were performed to inves-tigate the relationships between two independent groups. The significance level adopted for each test was 0.05. Table 3 presents the results of the performed statistical analysis. 


\section{ENTREPRENEURSHIP AND SUSTAINABILITY ISSUES}

ISSN 2345-0282 (online) http://jssidoi.org/jesi/ 2021 Volume 9 Number 2 (December) http://doi.org/10.9770/jesi.2021.9.2(3)

Table 3. Results of the performed statistical analysis

\begin{tabular}{|c|c|c|c|c|c|c|c|c|c|}
\hline Test & EDU & HEALTH & $\mathrm{JOB}$ & WAGE & COST & ENVIR & COMMUN & UTIL & CULTUR \\
\hline U Mann-Whitney & $\begin{array}{r}128263.5 \\
00\end{array}$ & 131481.000 & $\begin{array}{r}130370.5 \\
00\end{array}$ & 120673.000 & $\begin{array}{r}142419.5 \\
00\end{array}$ & 170519.500 & 127489.500 & $\begin{array}{r}147424 \\
.000\end{array}$ & 116520.000 \\
\hline W Wilcoxon & $\begin{array}{r}285343.5 \\
00\end{array}$ & 297081.000 & $\begin{array}{r}286890.5 \\
00\end{array}$ & 276076.000 & $\begin{array}{r}322119.5 \\
00\end{array}$ & 334970.500 & 289654.500 & $\begin{array}{r}305065 \\
.000\end{array}$ & 278116.000 \\
\hline $\mathrm{Z}$ & -6.340 & -7.490 & -6.011 & -7.906 & -4.598 & -.511 & -8.057 & -3.119 & -8.994 \\
\hline \begin{tabular}{|l|} 
Asymptotic \\
significance (two- \\
sided)
\end{tabular} & .000 & .000 & .000 & .000 & .000 & .609 & .000 & .002 & .000 \\
\hline
\end{tabular}

Source: own study based on the results of the CATI and CAWI survey on a sample of $n=1,233$ employers.

There are statistically significant differences between NUTS 2 regions for 8 factors, no significance was observed for environmental/recreational values (ENVIR). The value of the difference in the share of respondents' indications on the attracting and pushing role of specific factors, expressed in percentage points, is shown in Figure 2.

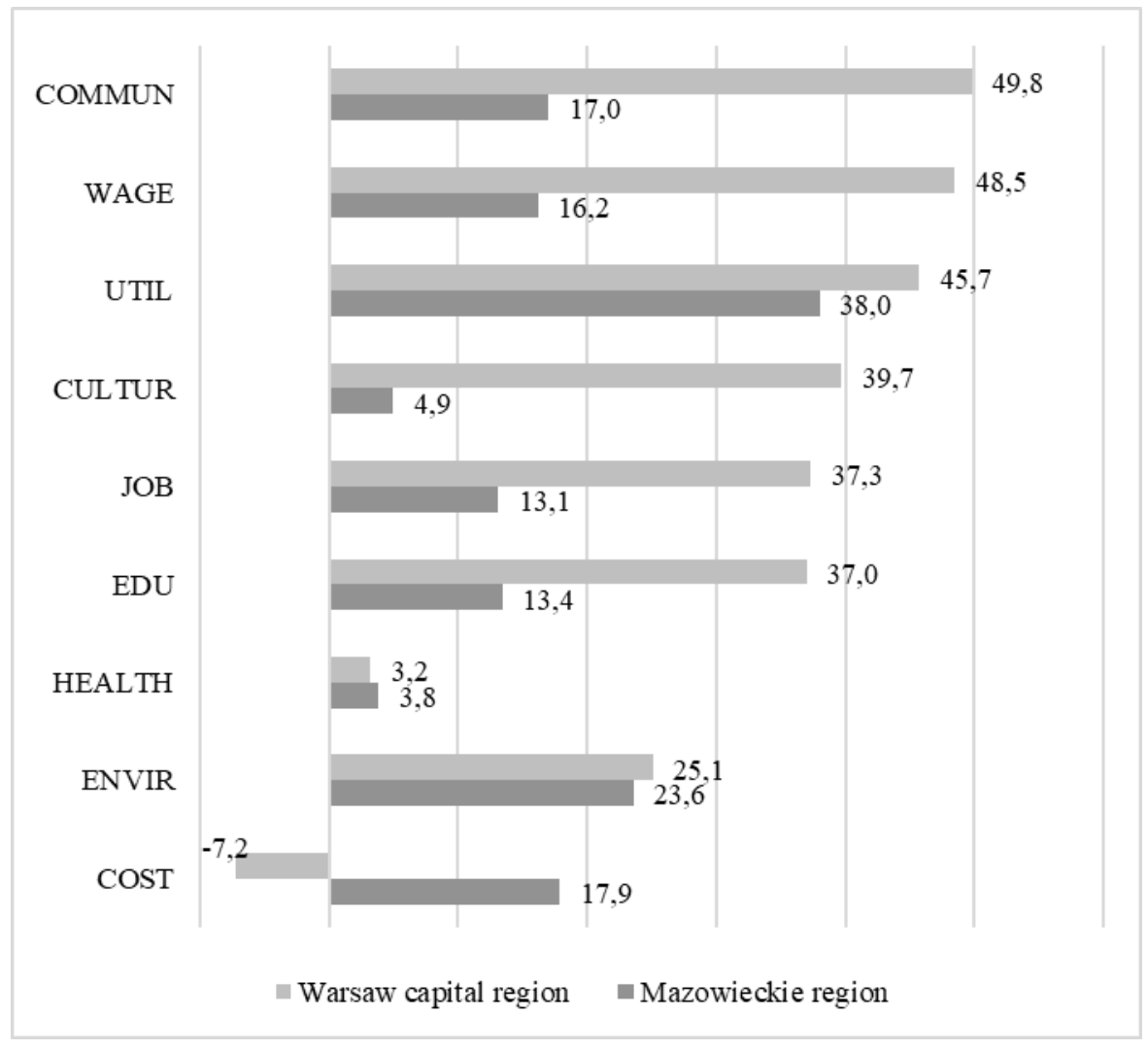

Figure 2. The difference (percentage points) between the responses indicating that a given factor attracts or pushes human capital out of the region

Source: own study based on the results of the CATI and CAWI survey on a sample of

$$
\mathrm{n}=1,233 \text { employers. }
$$




\section{ENTREPRENEURSHIP AND SUSTAINABILITY ISSUES}

ISSN 2345-0282 (online) http://jssidoi.org/jesi/ 2021 Volume 9 Number 2 (December) http://doi.org/10.9770/jesi.2021.9.2(3)

The main factors attracting human capital to Warsaw capital region are:

1. Level of communication with important centers (COMMUN).

2. The level of earnings (WAGE).

3. Accessibility of utility infrastructure (UTIL).

Relatively high power of attraction is related to the accessibility of cultural institutions (CULTUR), the number of jobs (JOB) and the availability of educational institutions (EDU). The only factor for Warsaw capital region, which had more indications as crowding than attractive, was the cost of living. It is worth emphasizing here that the extremely significant importance of the cost of living as a determinant of human capital migration was previously noted by, among others, N.B. Simpson (2017), G. Fields \& Y. Song (2020) and C.H. Mulder et al. (2020).

For Mazowieckie region, a higher percentage of responses indicating that a given factor attracts human capital occurs, in comparison with Warsaw capital region, only in the case of the cost of living (COST). The main factors attracting human capital to this region are:

1. Accessibility of utility infrastructure (UTIL).

2. Cost of living (COST).

3. Level of communication with important centers (COMMUN).

Particularly noteworthy in this context is the third factor, considered by the respondents as attractive. It should be emphasized that the level of communication of the Mazowieckie region with important centers was repeatedly raised in the public debate in the context of the phenomenon of communication exclusion of some areas of the region. It seems that the recognition of this factor as attractive is influenced by the structure of the research sample, which was included only by employers. Results could differ if other categories of respondents were also included in the sample.

The following are the factors that differed the most between regions:

1. Accessibility of cultural institutions (CULTUR).

2. Level of communication with important centers (COMMUN).

3. The level of earnings (WAGE).

4. Availability and level of healthcare (HEALTH).

The obtained results seem to confirm to a large extent a long-standing conviction about the strongest factors attracting and pushing human capital out of particular geographic areas. Invariably, one of the key determinants of migration remains the condition of the labour market and related level of wages. The importance of these factors was emphasized in the studies conducted by D.S. Kline (2003), G.S. Kainth (2009), F. Djafar (2012), V.P. Rosas \& A.L. Gay (2015), or D. Hare (1999). All mentioned authors drew attention to the fact that a large number of jobs in economically strong urban centres and the size of labor demand on their local labour markets is a factor attracting labour resources from rural areas, which may result in labor shortages appearing there.

Moreover, our results confirm the significant importance of the level of local infrastructure and transportation network between important economic centres as one of the important determinants of the movement of human resources between regions. The importance of this factor was emphasized by, among others, K.K. Thet (2014), who also recognized the importance of the environmental and recreational values of a given area, claiming that dissatisfaction with the state of the natural environment in close vicinity is one of the key factors prompting emigration. 


\section{ENTREPRENEURSHIP AND SUSTAINABILITY ISSUES}

ISSN 2345-0282 (online) http://jssidoi.org/jesi/ 2021 Volume 9 Number 2 (December) http://doi.org/10.9770/jesi.2021.9.2(3)

Relatively large disproportion in the assessment of the availability and level of healthcare, which was recorded in two studied regions, was previously diagnosed in scientific studies concerned with the so-called patient migration (see Cantarero, 2002; Levaggi \& Zanola, 2004).

\section{Conclusions}

The issue of determinants of redistribution, concentration and dispersion of human capital has been a popular research topic undertaken by representatives of social sciences for years. It is worth noting here that one of the basic factors determining the concentration of the discussed resources, as well as their dispersion, are the processes of population migration, which are a derivative of, inter alia, the diversification of the attractiveness of individual areas.

This paper deals with the issue of the level of human capital as one of the key determinants of the socio-economic development of Mazovia. The results of the author's empirical research were presented and discussed, the main aim of which was to diagnose the factors pushing out of and attracting human resources to individual regions of the Masovian Voivodship. Among the most important conclusions from the research carried out, it is worth pointing to the following:

1. Business owners in the Masovian Voivodship more often indicate the attracting role of various factors. Only the "cost of living" (COST) factor has been described as pushing human capital out of the Warsaw capital region. 2. Cost of living is a factor pushing away from the Warsaw capital region and at the same time pulling to the Mazowieckie region;

3. The level of communication with important centers, the level of earnings and the accessibility of utility infrastructure are the strongest factors attracting human capital to the Warsaw capital region;

4. According to the respondents, the Mazowieckie region is mostly attractive due to the accessibility of utility infrastructure, the cost of living and the level of communication with important centers . Especially the third of the above-mentioned factors seems to be in contradiction with the thesis, popular in the public debate, about the exclusion of peripheral areas of the Masovian Voivodship in terms of transport;

5. The accessibility of utility infrastructure is a strong point of the two regions included in the study;

6. Among the factors whose assessment varied the most between the regions, the following should be indicated: the accessibility of cultural institutions, the level of communication with important centers, the level of earnings and the availability of healthcare.

It seems that the differentiation of the attractiveness of the neighbouring regions is something natural, especially when one of them houses the largest and economically strongest agglomeration centre of a given country. The natural consequence is the high power of factors attracting human capital to it and the relatively high cost of living for its inhabitants. It is worth emphasizing here, that one of the key tasks facing by the state and local authorities is to ensure the sustainable development of peripheral regions. In light of the presented research results, the main areas of government intervention should include communication and transport infrastructure as well as primary healthcare facilities.

The research results presented in this article are based on the analysis of the opinions expressed by the employers. Undoubtedly, their comparison with the opinions expressed by other groups of potential respondents: e.g. employed people, unemployed people, professionally inactive, or representatives of various age categories would be of great cognitive value. The obtained research results are an inspiration to expand further research initiatives aimed at diagnosing the factors that attract and push out of particular regions. 


\section{ENTREPRENEURSHIP AND SUSTAINABILITY ISSUES}

ISSN 2345-0282 (online) http://jssidoi.org/jesi/ 2021 Volume 9 Number 2 (December) http://doi.org/10.9770/jesi.2021.9.2(3)

\section{References}

Aghion, P., Boustan, L.Hoxby, C. \& Vandenbussche J. (2009). The causal impact of education on economic growth: evidence from U.S. Harvard University.

Akcoraoglu A. (2010). Employment, economic growth and labor market performance: the case of Turkey. Ekonomik Yaklaşım, 21(77), 101-114.

Alhowaish, A. K. (2014). Healthcare spending and economic growth in Saudi Arabia: a Granger causality approach, International Journal of Scientific \& Engineering Research, 5(1), 1471-1476.

Amri, K. (2018). The macroeconomic impact of regional minimum wages: a cross-provinces data evidence from Indonesia. Regional Science Inquiry, 10(3), 163-176.

Angelini, F., \& Castellani, M. (2019). Cultural and economic value: a critical review. Journal of Cultural Economics, 43(2), 173-188. https://doi.org/10.1007/s10824-018-9334-4

Bakhshi, H., Fujiwara, D., Lawton, R., Mourato, S., \& Dolan, P. (2015). Measuring economic value in cultural institutions. Arts and humanities research council.

Banerjee, A., Duflo, E., \& Qian, N. (2012). On the road: Access to transportation infrastructure and economic growth in China (No. w17897). National Bureau of Economic Research.

Bartnik, K. (2016). Znaczenie kapitału ludzkiego i społecznego w rozwoju regionalnym na przykładzie Finlandii. Studia Oeconomica Posnaniensia, 4(6), 7-26. https://doi.org/0.18559/SOEP.2016.6.1

Becker, G.S. (1962). Investment in human capital: a theoretical analysis. The Journal of Political Economy, 70(5), 9-49.

Bedir, S. (2016). Healthcare expenditure and economic growth in developing countries. Advances in Economics and Business, 4(2), 76-86. https://doi.org/10.13189/aeb.2016.040202

Bijak J. (2006). Forecasting international migration: selected theories, models and methods, Warsaw: Central European Forum for Migration Research.

Bove, V. \& Elia, L. (2017). Migration, diversity, and economic growth, World Development, 89, 227-239. https://doi.org/10.1016/j.worlddev.2016.08.012

Cantarero, D. (2006). Health care and patients' migration across Spanish regions. The European Journal of Health Economics, 7(2), 114116. https://doi.org/10.1007/s10198-006-0341-6

Cutanda, A., \& Paricio, J. (1994). Infrastructure and regional economic growth: The Spanish case. Regional Studies, 28(1), 69-77.

Dańska-Borysiak, B. \& Laskowska, I. (2016). Kapitał ludzki i wzrost gospodarczy w podregionach. Wiadomości Statystyczne (Human capital and economic growth in subregions. Statistical News), 6, 31-44.

Diebolt C. \& Hippe R. (2019). The long-run impact of human capital on innovation and economic development in the regions of Europe. Applied Economics, 51(5), 542-563. https://doi.org/10.1080/00036846.2018.1495820

Djafar, F. (2012). Dynamics of push and pull factors of migrant workers in developing countries: The case of Indonesian workers in Malaysia. Journal of Economics and Behavioral Studies, 4(12), 703-711.

Doeringer P.B., \& Piore M.J. (1971). Internal labor markets and manpower analysis, Lexington: D.C. Heath Company.

Donou-Adonsou, F. (2019). Technology, education, and economic growth in Sub-Saharan Africa,Telecommunications Policy, 43(4), 353360. https://doi.org/10.1016/j.telpol.2018.08.005

Faggian. A. \& McCann, P. (2009). Human capital and regional development. In R. Capello \& P. Nijkamp (Eds.). Handbook of regional growth and development theories. Edward Elgar Publishing Limited. 


\section{ENTREPRENEURSHIP AND SUSTAINABILITY ISSUES}

ISSN 2345-0282 (online) http://jssidoi.org/jesi/ 2021 Volume 9 Number 2 (December) http://doi.org/10.9770/jesi.2021.9.2(3)

Fields, G., \& Song, Y. (2020). Modeling migration barriers in a two-sector framework: A welfare analysis of the hukou reform in China. Economic Modelling, 84, 293-301. https://doi.org/10.1016/j.econmod.2019.04.019

Florida, R. (2002). The rise of the creative class and how it's transforming work, leisure, community and everyday life. New York: Basic Books.

Gennaioli, N., La Porta, R., Lopez-de-Silanes, F. \& Shleifer, A. (2013). Human Capital and Regional Development. The Quarterly Journal of Economics, 128(1), 105-164. https://doi.org/10.1093/qje/qjs050

Goldin, C. (2019). Human capital. In C. Diebolt \& M. Haupert (Eds.). Handbook of Cliometrics. Berlin, Heidelberg: Springer International Publishing.

Grossman, G. M., \& Krueger, A. B. (1995). Economic growth and the environment. The quarterly journal of economics, 110(2), 353-377.

Hare, D. (1999). 'Push'versus 'pull'factors in migration outflows and returns: Determinants of migration status and spell duration among China's rural population. The Journal of Development Studies, 35(3), 45-72.

Harris J. R. \& Todaro M. P. (1970). Migration, unemployment and development: A twosector analysis. American Economic Review, 60(1), 126-142.

Herbst, M. (2007). Kapitał ludzki i kapitał społeczny a rozwój regionalny (Human and social capital and regional development). Warsaw: Wydawnictwo Naukowe Scholar.

Herranz-Loncán, A. (2007). Infrastructure investment and Spanish economic growth, 1850-1935. Explorations in Economic History, 44(3), 452-468. https://doi.org/10.1016/j.eeh.2006.06.002

Horii, R., Kitagawa, A. \& Futagami K. (2008), Availability of higher education and long-term economic growth. The Japanese Economic Review, 59(2), 156-177. https://doi.org/10.1111/j.1468-5876.2007.00403.x

Humphries, J., \& Weisdorf, J. (2019). Unreal wages? Real income and economic growth in England, 1260-1850. The Economic Journal, 129(623), 2867-2887.

Jerome, A. (2011). Infrastructure, economic growth and poverty reduction in Africa. Journal of infrastructure development, 3(2), 127-151.

Kainth, G.S. (2009). Push and pull factors of migration: a case of brick kiln industry of Punjab State. Asia-Pacific Journal of Social Sciences, 1(1), 82-116.

Khoshnevis Yazdi, S., \& Khanalizadeh, B. (2017). Air pollution, economic growth and health care expenditure. Economic researchEkonomska istraživanja, 30(1), 1181-1190. https://doi.org/10.1080/1331677X.2017.1314823

Kijek, A., \& Matras-Bolibok, A. (2020). Technological convergence across European re-gions. Equilibrium. Quarterly Journal of Economics and Economic Policy, 15(2), 295-313. https://doi.org/10.24136/eq.2020.014

Kline, D. S. (2003). Push and pull factors in international nurse migration. Journal of nursing scholarship, 35(2), $107-111$.

Kuc-Czarnecka, M. (2019). Sensitivity analysis as a tool to optimise Human Development Index. Equilibrium. Quarterly Journal of Economics and Economic Policy, 14(3), 425-440. https://doi.org/10.24136/eq.2019.020

Lee E.S. (1966). A theory of migration. Demography, 3(1).

Lee, S. Y., Florida, R., \& Acs, Z. J. (2004). Creativity and entrepreneurship: a regional analysis of new firm formation. Regional Studies, 38(8), 879-891. https://doi.org/10.1080/0034340042000280910

Levaggi, R., \& Zanola, R. (2004). Patients' migration across regions: the case of Italy. Applied economics, 36(16), 1751-1757. https://doi.org/10.1080/0003684042000227903

Massey D.S., Arango J., Hugo G., Kouaouci A., Pellegrino A. \& Taylor J.E. (1993). Theories of international migration: review and appraisal, Population and Development Review, 19(3), 349-354. 


\section{ENTREPRENEURSHIP AND SUSTAINABILITY ISSUES}

ISSN 2345-0282 (online) http://jssidoi.org/jesi/ 2021 Volume 9 Number 2 (December) http://doi.org/10.9770/jesi.2021.9.2(3)

Mulder, C. H., Lundholm, E., \& Malmberg, G. (2020). Young Adults' Migration to Cities in Sweden: Do Siblings Pave the Way?. Demography, 57(6), 2221-2244. https://doi.org/10.1007/s13524-020-00934-Z

Niedzielski, P., Poznańska, K. \& Matusiak, K.B. (2009). Kapitał ludzki-innowacje -przedsiębiorczość. Zeszyty Naukowe Ekonomiczne Problemy Ustug, (Human capital - innovation - entrepreneurship. Scientific Notebooks Economic Problems of Services), 525, $333-342$.

Outreville, J.F. (1999). Finacial development, human capital and political stability. UNCTAD Discussion Papers 142, United Nations Conference on Trade and Development.

Palei, T. (2015). Assessing the impact of infrastructure on economic growth and global competitiveness. Procedia Economics and Finance, 23, 168-175. https://doi.org/10.1016/S2212-5671(15)00322-6

Panayotou, T. (2016). Economic growth and the environment. The environment in anthropology, 140-148.

Pasinetti, L.L. (1962). Rate of profit and income distribution in relation to the rate of economic growth. Review of Economic Studies 29(4), 267-279.

Piore M., (1979). Birds of passage: migrant labour and industrial societies, Cambridge: Cambridge University Press.

Pritchett, L. (2001). Where has all the education gone? World Bank Economic Review, 15, 367-391.

Przygodzki, Z. (2019). Terytorialny wymiar kapitału ludzkiego. Gospodarka Narodowa, no. 4(300), 105-130. https://doi.org/10.33119/GN/113513

Romer, P.M. (1989). Human capital and growth: theory and evidence. National Bureau of Economic Research (NBER), Working Paper, no. 3173 , pp. 1-51.

Rosas, V. P., \& Gay, A. L. (2015). Push and pull factors of Latin American migration. In A. Domingo Valls, A. Sabater Coll, R. Verdugo (Eds.). Demographic analysis of latin american immigrants in Spain. Springer, p. 1-27. https://doi.org/10.1007/978-3-319-12361-5_1

Schultz, T.W. (1961) Investment in human capital. The American Economic Review, 51(1), 1-17.

Seyfried, W. (2005). The relationship between employment and economic growth in the ten largest states. Southwestern Economic Review, Spring, 13-24.

Simionescu, M., Lazányi, K., Sopková, G., Dobeš, K. \& Balcerzak A.P. (2017). Determinants of economic growth in V4 countries and Romania, Journal of Competitiveness, 9(1), 103-116. https://doi.org/10.7441/joc.2017.01.07

Simpson, N.B. (2017). Demographic and economic determinants of migration. IZA World of Labor.

Som, J., Pasal, S., \& Kaboine, M. (2019). Exploring the impact of healthcare on economic growth in Africa. Applied Economics and Finance, 6(3), 45-57. https://doi.org/10.11114/aef.v6i3.4110

Thet, K. K. (2014). Pull and push factors of migration: A case study in the urban Area of Monywa Township, Myanmar. News from the World of Statistics, 1(24), 1-14.

Tian, G., \& Li, J. (2019). How does infrastructure construction affect economic development along the "belt and road": by promoting growth or improving distribution?. Emerging markets finance and trade, 55(14), 3332-3348. https://doi.org/10.1080/1540496X.2019.1607725

Toader, E., Firtescu, B. N., Roman, A., \& Anton, S. G. (2018). Impact of information and communication technology infrastructure on economic growth: An empirical assessment for the EU countries. Sustainability, 10(10), 3750. https://doi.org/10.3390/su10103750

Tselios V., Rovolis A. \& Psycharis Y. (2017). Regional economic development, human capital and transport infrastructure in Greece: the role of geography. In: M. Fonseca \& U. Fratesi (Eds.). Regional upgrading in Southern Europe. Advances in spatial science (the regional science series). Springer.

Williams, A. M., Baláž, V., \& Wallace, C. (2004). International labour mobility and uneven regional development in Europe: human capital, knowledge and entrepreneurship. European Urban and Regional Studies, 11(1), 27-46. https://doi.org/10.1177/0969776404039140 


\section{ENTREPRENEURSHIP AND SUSTAINABILITY ISSUES}

ISSN 2345-0282 (online) http://jssidoi.org/jesi/ 2021 Volume 9 Number 2 (December) http://doi.org/10.9770/jesi.2021.9.2(3)

Wiśniewska, A., Budziński, W., \& Czajkowski, M. (2020). An economic valuation of access to cultural institutions: museums, theatres, and cinemas. Journal of Cultural Economics, 44(4), 563-587. https://doi.org/10.1007/s10824-020-09375-3

Zajączkowska-Jakimiak, S. (2006) Wiedza techniczna i kapitał ludzki w teorii wzrostu gospodarczego. Gospodarka Narodowa (Technical knowledge and human capital in the theory of economic growth. National Economy), 11-12, 47-69.

\section{Acknowledgements}

The study was carried out as part of the "Sustainable development of the Masovian Voivodship in the new system of NUTS2 and NUTS3 units. Metropolitan, regional and sub-regional level "project, implemented under the strategic research and development program: "Social and economic development of Poland in the conditions of globalizing markets GOSPOSTRATEG". The project was financed by the National Centre for Research and Development (grant agreement number: Gospostrateg1/388207/9/NCBR/2018).

\section{Marek PIOTROWSKI}

ORCID ID: orcid.org/0000-0002-1977-5995

\section{Paweł HURAS}

ORCID ID: orcid.org/0000- 0003-3288-5993

Katarzyna MODRZEJEWSKA

ORCID ID: orcid.org/0000- 0003-4382-3157

Make your research more visible, join the Twitter account of ENTREPRENEURSHIP AND SUSTAINABILITY ISSUES: @Entrepr69728810 